\title{
ON THE CUSTOMS RELATED TO DEATH IN THE ERZA VILLAGES OF SABAJEVO AND POVODIMOVO
}

\section{Marika Mikkor}

We might say that the Mordvin people are the most scattered kin tribe of the Estonians, as they have settled in the area stretching from the Mid-Russia to the Siberia and can be found even in the Central Asia. As to the linguistic, cultural and anthropological aspect they are divided in two major groups - the Moksha and the Erza, whereas the latter are considered the close kindred people of the Baltic-Ugric people (Uibopuu 1984: 203).

The present overview is based on the material collected on my two brief expeditions to Sabajevo village in 1988 and to Povodimovo village in 1989. The objective of the expeditions was to gather some comparative material on the funeral and birth customs of the Caucasian Estonians. The material I have collected is maintained in the Estonian National Museum (EA 218) and I have published two articles on the topic in the Yearbook of Estonian National Museum (Mikkor 1994b, Mikkor 1998).

Both villages are located in the Mordvinian Republic: Sabajevo village in the district of Kochurovo and Povodimovo in the district of Dubjonki. Culturally the villages are located in the area of relatively uniform mono-ethnic population with a strong tradition of national culture. The neighbouring people of the Mordvinians are the Orthodox Russians and the Muslim Tartars. Regardless of the Russian language schools and other factors favouring the assimilation process, the Mordvinians have retained their language as well as national identity in rural regions. Partly, of course, it might be attributed to the relatively wide-spread illiteracy among the elderly up to the present time.

The population of both villages was approximately 3.000 inhabitants; the majority of them were the Erza-Mordvinians who communicated in the Erza language. Both villages had their own school, recreation centre, diner, café, stores, post-office and kindergarten. In addition, there is a school museum and a monument at the place 
of a destroyed church to those who died during WWII in Sabajevo, and a small elastic tape factory and a larger number of general stores in Povodimovo. Sabajevo village seemed more backward with a single flowerbed and rank weed growing everywhere (“... as if planted there" - R. Alatalu); when it rained the village streets resembled a muddy potato field. But inside the houses were impeccably clean. In Povodimovo the number of young people was larger, a lot of new houses had been built, the village streets were paved, the houses surrounded with planted flowers and well-kept vegetable gardens and orchards.

The tradition of the ancient material culture has survived longest in Sabajevo village. Up to the present day the wedding hostess wears national costume for ritual purposes. The district of Kochkurovo, in fact, is known as a region where national costume was worn longer than anywhere else in Mordvinia. Literary sources reveal that they were used as ceremonial clothes up to $1960 \mathrm{~s}$ (Mordovski 1990: 38). And, as already mentioned, people in Sabajevo village wear national costume up to the present day.

Urban culture reached Povodimovo earlier and its influence there is considerably stronger than in Sabajevo. The custom of wearing national costumes became obsolete already in the 1920s-1930s. The traditional women's clothing became to be a jacket and a skirt in urban style. The same tendency was prevalent in the rest of Mordivinia (Mordovski 1990: 12-14; Luzgin \& Mezin 1986: 121). Jacket and skirt were originally intended for bridal wear and were later even considered as a national costume. In modern times, jacket and skirt are worn as ceremonial dress by the wedding hostess. Today, the middle-aged and elderly women dress quite alike, wearing a long-sleeved dress with cuffs and collar, cut and gathered in the waist and buttoned in front, a dark apron with a front and a triangular white head-cloth. This outfit has become traditional as well.

The language of the Mordvinians in Povodimovo village contains more Russian loanwords than that in Sabajevo, whereas the feeling of national identity was considerably stronger in Povodimovo, where people considered themselves better, cleaner and more hardworking than the neighbouring Russians. 
Most of the Mordvinians are Russian Orthodox, and so was the population of the villages under discussion. Christian religion was adopted among the Mordvinians only in the 18th century, therefore they were regarded as the "last heathens" in Europe (Uibopuu 1984: 205). Today, the elderly and most of the middle-aged women appear to be earnest believers. The churches of Sabajevo and Povodimovo were destroyed in the 1920s-1930s, but till the present day every farm house has its own altar corner. Children are baptised in town churches. Also, church weddings are rather rare. Funeral ceremonies are carried out by women in the village, and former church holidays are beginning to lose their significance.

Below I intend to describe both living as well as obsolete ritual ceremonies and beliefs connected to death and funerals. The earlier Mordvin funeral customs have also been discussed in the works of I. Smirnov, H. Paasonen, A. Hämäläinen, U. Harva, T. Fedianovich and D. Zelenin.

\section{DEATH}

The approaching death was predicted by the unusual behaviour of birds. A hawk making noise and flying over the yard predicts an imminent death caused, for instance, by an accident. A bird knocking at the window might bring both good as well as bad tidings. In Povodimovo, for example, a pigeon knocked at the window of a woman whose son died soon after that. A magpie chattering outside was asked: "Magpie, magpie, if you sing of good then go on singing, if you sing of bad, then be quiet." And if the bird flew off, it denoted misfortune.

An accident or death was often foretold from voices, calls and knockings of unknown origin. A strange call was usually returned by asking - "Is it good or not?" If the voice replied - not, not! then it meant misfortune, the person became seriously ill. If someone's name is called once, the person called should not reply. The call could be replied only after the third call: then one could be certain that he/she was called by a human being. A week before the Easter holidays somewhere in the 1980s a Sabajevo woman heard a familiar voice calling her by the name. She replied and went outside, but there was noone there. On the Easter Monday she suffered a 
bad fall and died. Sometimes people have heard walking upstairs or knocking on the door. The rattler is believed to be a relative of the deceased who senses that something bad is going to happen to the living, and is therefore restless. All the omens described thus far are universally known (Mikkor 1996).

In Sabajevo it was believed that more people die at the turn of the year. If a year starts with the death of a young person, it is believed that more young people are going to die during the year, if the year starts with a death of an elderly person, then the older people will die. The omens of the surrounding nature might predict death both for healthy as well as sick persons, and they come true in either a shorter or longer period of time.

When an ill person is dying (kulõma) he becomes more agitated and lively before the departure, some want to eat different foods, others wish to drink water from another well, or move to another bed or lay on the floor. Some come up from their sickbed and go outside. After the death such details are taken as omens. Those around someone's deathbed keep very quiet to prevent the dying person's hovering between life and death. The ancient custom of moving a dying person to either a bench or floor has become obsolete, and is now done only on the latter's wish. People of Povodimovo recalled a former custom of moving a dying person to a straw bed.

To enable one's soul depart easier and faster, a feather pillow is taken from under the sick one's head. The tradition is still followed even in local district hospitals. Dying on a feather pillow is not just more difficult, it is also considered a sin, and the one who dies his head on a feather pillow must start counting the feathers in the other world (toonachi). The Cheremis (Mari) people believed the same (Holmberg 1914a: 12). The East-Slavonic people believed that the one who died on feathers will not be absolved (Smirnov 1920: 27 ), or that every single feather causes more sufferings for the person (Zelenin 1927: 320). The original belief was that the departing soul will impede in feathers. Such beliefs connected to feather pillows are common among Orthodox as well as Lutheran peoples (Harva 1935: 105; Sartori 1910: 126; Päss 1939: 200; Salmio 1976: 29), by now, however, they have mostly been forgotten. At its later stage the custom forbade placing a feather pillow in the coffin (Konkka 1985: 56; Mikkor 1994a: 1258). 
The head of a dying person was placed on a pillow stuffed with straw or a bundle of cloth.

Even today people in Mordvinia remember beliefs related to the departure of the souls of the evil ones and witches (koldunatja or koldun baba - in Povodimovo). Their death could be made easier by the confession of misdeeds and praying. When a witch died the ceiling boards had to be broken loose in Povodimovo, whereas the people in Sabajevo remembered that a witch could die only after someone had agreed to take over the skills. The witch was supposed to spit thrice into the apprentice's mouth. Whether oral tutoring was also necessary was not remembered. The opening of ceiling and roof boards to ease the death is a well-known folkloric custom (Clemen 1920: 21; Sartori 1910: 127; Juvas \& Reponen 1939: 283; Kemppinen 1967: 27; Mikkor 1994a: 1240; 1995: 1892; Salmio 1976: 29), still, its later stage - the opening of windows (Ränk 1949: 46) - was not considered significant among the Mordvin people. A common knowledge was that a witch had to find a successor before his death.

For the time of departure all mirrors and reflecting surfaces in the room are covered with a towel. Some people believe it to ease the

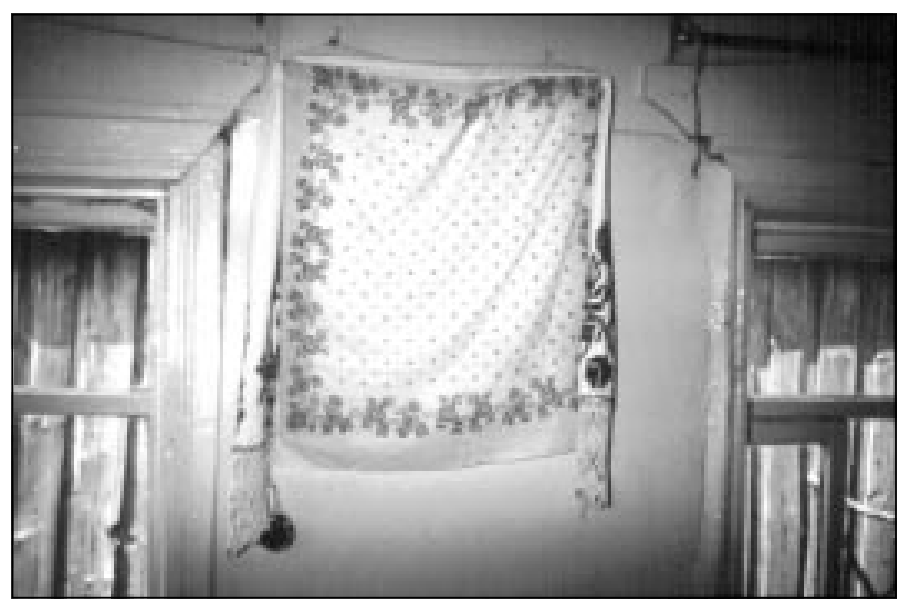

Photo 1. For during the spirit's leaving time, mirrors as well as other reflecting surfaces are covered up with a towel. Some believe this to ease the situation for the dier, while others consider reflection dangerous for the living. July, 1989, Povodimovo. Photo by Riin Alatalu 
sufferings of the dying person, others consider the reflection dangerous for the living present in the room.

In Sabajevo a glass of water and a piece of bread is placed on the table, and a glass of honey in the altar corner. During the forty days after the person's death when the soul is believed to be around, fresh water and bread are put on the table every day, as it is believed that the soul of the deceased will eat and drink them. Honey is a traditional funeral food among the Russian Orthodox peoples. In Greece, honey was thought to have magical powers protecting against various evil forces (Samter 1901: 84). For the same reason the Mordvinians used to spread honey on the dying person's lips if he happened to salivate (Harva 1942: 19). It has been argued that the custom of placing food near the dying person originates from the custom of the Orthodox peoples who used to place food to the grave, a tradition strongly objected by the clergy. The East-Slavonic people and Caucasians substituted the water with either vodka, wine or kvass (Kulikovski 1890: 56-59; Dzhanashvili 1893: 159; Mamaladze 1893: 85; Iashchurzhinski 1898: 93-94; Sagaradze 1899: 19; Abramov 1907: 29; Zavoiko 1914: 87; Bogoslavski 1924: 75; Zelenin 1927: 320; Chursin 1956: 195; Veletskaia 1968: 195).

At the same time the people of Sabajevo believe that within the forty days the deceased one visits all the places where has been during his lifetime. (This idea is very popular among the Russian Orthodox peoples) (Lenchevski 1899: 78; Lukkarinen 1914: 4; Haavio 1934: 85; Itkonen 1948: 356; Pentikäinen 1971: 202). On the ninth day, the departed one returns home and a feast is held in his memory. After forty days the soul ascends to heaven, and again it is celebrated with a feast. The travelling of souls is still strongly believed: a middle-aged village woman told me in 1988 that after death I will have to come and visit Mordvinia. So, apparently it was thought that the soul travels around and, simultaneously hovers around the homestead.

For the moment of death a glass of water is placed in the altar corner, and an iconic scarf kõrgapatsja (i.e. a kerchief) hanged between the altar corner and the nearest window in Povodimovo. (The kõrgapatsja is a part of the ritual Povodimovo clothing, worn around the neck by a bride and the wedding hostess. The scarf is adorned with lavish embroidery in Russian style). People believed that the 
soul departing the body goes first to the water and then into the scarf. During six weeks the soul was thought to stay under the scarf and drink water. On the commemoration feast forty days after the death all women wail, kiss the scarf and wipe their faces with it to take their leave with the finitely departing soul. On the feasts held half a year and a year after the death the scarf is hanged back on the wall. In older times people used to wail over the clothes of the departed one placed on the death bench when he was still home or during commemoration days (Zelenin 1915: 980; Hämäläinen 1927: 134; Hämäläinen 1930: 121; Zelenin 1938: 90); later, the clothes were substituted with the scarf. The Russian Orthodox peoples associated the scarf hanged on the wall of a room or a farmhouse with various beliefs (Zelenin 1927: 320; Vilkuna 1989: $269 \mathrm{ff}$ ): the Raskolniks or the Russian Old Believers, for example, are known to have a belief analogous to the aforementioned (Bogoslavski 1924: 75). Wailing over the clothes was common for other peoples as well, such as the Chuvash, Abkhazian and Caucasian tribes (Dzhanashvili 1893: 159; Chursin 1956: 186, 188, 189; Volkova 1978: 34). According to A. Vilkuna the custom of hanging the scarf on the wall was not typical of the early Mordvinians (Vilkuna 1989: 269), still, a report from that period refutes this argument (Paasonen 1939: 505).

In Povodimovo food and beverage was placed on the table for the deceased. Thus, at some places water was intended for the soul to wash in it, at others it served as a drink. Here the different layers of religious concepts interrelate closely. The Veps people, for instance, placed water for washing at some places and for drinking at others, too (Strogalshchikova 1986: 67, 68).

People started to place objects like money, food stuff, clothes, favourite belongings, etc. that were formerly put in the grave to a window sill near the deceased (Zelenin 1915: 972; Fedianovich 1990: 99). The belief in the soul's washing itself is universal. The Russian Orthodox peoples believed that a soul departs into the water and washes itself there (Lukkarinen 1914: 1; Juvas \& Reponen 1939: 283; Zelenin 1927: 320; Loorits 1949: 73). In 1989, a report from Ingria says that the soul is gargling with the water (Mikkor 1995: 1892). The Muslim Arabs, on the other hand, poured water down the throat of the dying one in order to "wet" the soul (Granqvist 


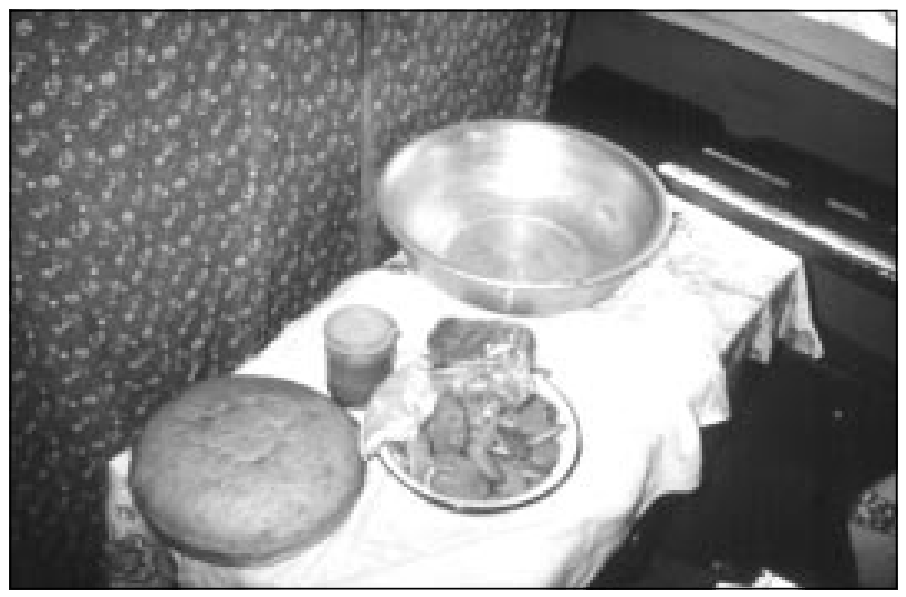

Photo 2. In Povodimovo it was said that for during the time of the spirit leaving, a glass of water was put into the holy corner so that the spirit could go into water after leaving its body; after death the table was covered with food and beverages. However, the basin of water seen in July, 1989 in the dead's chamber would be more suitable for washing; bread, biscuits and honey were food for the deceased.

1965: 51, 52), whereas a Slovenian mountain tribe poured water in the dying one's face (Kotliarevski 1891: 210).

As soon as the soul has departed, the deceased one's (kuloman) eyes and mouth is closed. Often the eyes were covered with 5-copeck coins, as leaving the eyes open was believed to predict another death in the family.

Literary sources reveal that in older times the person's face was covered with a sheet already before his death so that on the moment of the soul's departure his glance would not fall on those alive and could not take them along (Harva 1942: 19). The accounts about covering eyes and mouth before death are known from several peoples (Rosenplänter 1823: 32; Päss 1939: 198; Salmio 1976: 27, 28; ERA II 200, 164 (51) < Tallinn).

After the death all female relatives begin wailing. 


\section{THE WASHING AND DRESSING OF THE DECEASED}

With the spread of the news about someone's death all neighbouring women gather to the house of mourning. People to wash the deceased are called and the water heated. Usually the elderly people had prepared for the death having a soap and a towel ready and having named the persons to wash them. The washers were three or four elderly people, either relatives or neighbours, but never close relatives. The deceased is washed sitting on a bench, its feet in a water tub. Literary material suggests that the dead one was washed most often lying on the straws spread on the floor or in its deathbed. The washing in the sitting position was known at some places in Estonia, Karelia and also among the Livonians and the Belorussians (Raadla 1939: 19; Loorits 1932: 181; Juvas \& Reponen 1939: 284; Shein 1890: 561).

One of the people assisting the washing supports the dead body, another one pours water and all others scrub the body with soap and a sponge. After it is done, all those who had touched the body wash their hands and face with the soap used for washing the deceased in order to protect them against diseases. Then the soap is handed over to the housewife. After contact with the deceased the soap was attributed special healing powers, which were thought to be particularly effective against eye diseases, but would also heal wounds, dermatological diseases, etc. The housewife had to take extra care to see that noone would steal the precious curative. In Ingria the soap was given to the washer of the deceased (Mikkor 1995: 1895), the same was common at some places in Estonia as well. The use of a soap used at washing the dead for magic and cure is known all over the world; today the custom has become obsolete among many peoples. Washing with soap and water has often been substituted for cleansing with spirit, which, again, favours the forgetting of such customs. Regardless of that, such a soap was used as a curative not so long ago in Võrumaa, Estonia.

The water used for washing the dead was usually poured out in the yard to the corner of the house closest to the altar corner, or the paazan uugol. Less often it was poured under a tree so as to prevent people from stepping on it, which would be considered a sin. A woman in Sabajevo recalled that stepping on the water used for 
washing the deceased could make the person ill. The water has also been used for putting a drunkard off liquor by making him drink that unconsciously. This universally known curing method was known in Ingria as late as in 1989 (Mikkor 1995: 1895). According to literary sources, the Mordvinians used to keep the water in a clay-pot inside the house during the wake period, for the funeral it was taken to the cemetery with coffin shavings (Zelenin 1938: 90, 91).A. Hämäläinen has written that the water was poured on the floor under a bench closest to the altar corner (Hämäläinen 1927: 128; Hämäläinen 1930: 130). Taking the water to the graveyard or pouring it to the place off the beaten track was common everywhere, whereas the Russian Orthodox peoples favoured the custom of pouring it outside to the corner closest to the altar corner. The author of the present article has not heard of other accounts from either the Mordvinians or other peoples about pouring the water on the floor inside the house. Also, the customs and beliefs connected to the supernatural powers of the water used for washing the deceased are falling into oblivion both in Povodimovo as well as Sabajevo village. The soap used for the same purpose, however, is used even today.

In earlier times the Mordvinians took all the objects, including the drying towel that had been in contact with the deceased to the graveyard or elsewhere off the beaten track. A report from Povodimovo describes the preventive magic powers of the towel. On a feast celebrated nine days after the death, a sauna is heated where all the people assisting the washing are invited. After the sauna all the washers dry themselves with the towel used for drying the deceased (which has been previously washed), and the towel is given to one of the washers. People who had been in contact with a dead body have always been considered unclean and dangerous until their purification (Frazer 1974: 271). And in Povodimovo and Sabajevo the danger from the contact with the dead body was washed off with a soap and towel used at the deceased.

Nowadays, however, the washers in Povodimovo are usually given a new towel. In Sabajevo I heard that earlier the washers were not given anything. Today the washers get towels, scarf and fabric in both villages. The Sabajevo women called it a "Russian habit". 
The washing is followed by dressing the deceased. The elderly people, especially women, use to prepare their grave-clothes, or the kuloman odjezhat before the death. In earlier times the dead were buried in a national costume sewn from white hempen linen adorned with colourful woolen embroidery. A deceased woman was clothed in a set of national dress combined of a shirt - panar, a robe - rutsja, a head-dress - koosinka, an apron - ikilga patsja, foot-rags praakstat and birch-bark shoes - kaart. The national costume of the living differed from that of the dead in that the latter were not dressed in the pulai, or the back apron. Before, the embroidery on the clothes of the deceased was more modest than on that of the living: the grave-clothes were generally sewn for that specific purpose. In Povodimovo the grave-clothes were embroidered only with black and red threads, the embroidery on the clothes of the living people were also green and yellow. The grave-clothes of the Izhorians and the Veps people, for example, could never have coloured embroideries. It was believed that the deceased who was buried in such clothes was in the other world sent under the eaves to drench or bleach in the sun until the embroidery lost its colour (Mikkor 1995: 1897; Strogalshchikova 1986: 70).

In Sabajevo the embroidery on the clothes of the living was of redbrownish, dark blue and green colour. The author of the current article has not found any information about the grave clothes. The last people buried in national costume wore a conventional national costume. In Povodimovo the last women buried in national dress were buried during 1920s-1930s. In Sabajevo the custom was still followed in 1940s-1950s. Even today some Sabajevo women keep a national costume for grave clothes, more often it is only a single item that is kept - either a shirt or birch-bark shoes. The keeping of national costume which is not worn in everyday life any more for grave-clothes is common to a number of peoples (Manninen 1957: 78; Shangina 1984: 203). The East Slavonic peoples had a tradition of putting birch-bark shoes on the deceased, even though he never wore it during his life (Maslova 1984: 91).

Specific grave-clothes had to be sewn by hand, basted with loose stitches without making a burl to the thread. The burls were believed to disturb the deceased in the other world. It has been assumed that such requirements known all over the world applied 
only to the clothes sewn after the person's death. But as the elderly people had their clothes ready already before death, the restrictions must have been followed particularly during unexpected or unusual deaths which were considered extremely dangerous (Fursova 1983: 83).

Today, such restrictions are becoming obsolete in both Sabajevo and Povodimovo. The shroud of hempen linen called oodra in Sabajevo and langavjälks in Povodimovo was to be torn from the fabric: it could not be cut out with scissors and the edge of the fabric was torn with the help of teeth. The significance of tearing the fabric for either grave-clothes, savan, shroud or a face cover was common also among other peoples (Shein 1890: 540; Smirnov 1920: 29; Malia 1982: 104; Maslova 1984: 86; Storgalshchikova 1986: 72). The same applies to the restrictions in sewing, which originally concerned grave-clothes, but later only the savan and shroud. The Livonian custom, for example, forbade tearing thread with one's teeth, as it would mean biting the deceased (Loorits 1932: 183).

The pieces of cloth that were left over after sewing the grave-clothes were burnt. The hair of deceased women were plaited in two pigtails each made of four strands, whereas the hair of the living was usually plaited of three or five strands. The braids of the dead were plaited reverse, a fact also mentioned in the earlier material on the Mordvin people (Harva 1942: 20), as well as among the Karelians (Konkka 1985: 46). In 1980s the Ingrians still remembered the requirement of plaiting pigtails "counter-clockwise" from four strands. Such tradition has a universal background, as it was important to treat the dead contrary to the living.

In Sabajevo a bun similar to that of the living was plaited on the forehead of a deceased married woman, it was covered with kaholka and the head-dress koosinka. In Povodimovo the braids were plaited around the woman's head, covered with a head-dress kolbak and two bright-coloured triangular scarves. The first scarf was tied on the back of the neck, and the second one under the chin. The Moksha-Mordvin women wore two scarves tied in this manner in everyday life (Luzgin \& Mezin 1986: 123). Tying the scarves in this way for the grave is mentioned in the literary sources about the Mordvinians (Fedianovich 1990: 114), and was common among 
other Russian Orthodox peoples, too (Päss 1939: 207, 225; Fursova 1983: 73). Today, the women of Sabajevo and Povodimovo tie only one scarf around the head of the deceased.

In earlier times the head of the deceased in Povodimovo was covered with a hood-like head-dress called oodrasava, very common among the Russian Orthodox people. The head-dress covered the head and the back of a person in full length (see Smirnov 1920: 29; Zelenin 1927: 322; Manninen 1957: 78; Shangina 1984: 203; Konkka 1985: 46). The Ingrians, for example, believed that the hood protected the dead against burning while passing the sea of fire in the other world (Mikkor 1995: 1898). In some places, however, the savan was known only among the Raskolniks (Fursova 1983: 84). Even in Estonia men are said to have been buried with a storm hood-like head-dress during the Middle Ages (Selirand 1974: 129).

The feet of the dead were covered with foot-rags and birch-bark shoes, whereas the laces of the shoes were tied with a single knot, as the deceased was not supposed to walk in them. In earlier times the shoe laces were tied reverse from the shoes of the living (Harva 1942: 20).

In Povodimovo, people used to keep urban-style wedding clothes, i.e. a dress and a jacket for their grave-clothes. The clothes were also used for ritual purposes by the wedding hostess. The peasants attributed magic powers to the things used at or brought to church ceremonies, and the same applied to wedding clothes (Maslova 1984: 129).

Nowadays, the deceased are dressed in the "Russian way" in both villages. The elderly women are dressed in a dark-coloured longsleeved tight dress with a cut waistline that has become a traditional clothing in everyday life. The feet are usually covered with slippers to make her walk more comfortable. Those who have died in a young age are dressed in modern clothes and shoes. 


\section{THE DECEASED AT HOME}

In the chamber the dead who had been attended used to be laid on a bench at the wall. Today they are laid on the dining-table with its head towards the altar corner and feet towards the door. The hands of the deceased are folded on its stomach. Both hands and feet are tied up in order to keep them together. Before burial the limbs are untied again, as the deceased must be able to move in the other world. Also, he could not confront the God with tied hands and feet. The bonds are either placed in the coffin or used for magic, as people believe they can cure diseases or put a person off liquor. For the latter the bonds were secretly sewn inside the clothes, say, in a pocket of a drunkard's coat. Same treatment was used to prevent a man from beating his wife. If someone had a case in court he was supposed to place the bonds into his pocket to guarantee good luck. A ring or a cross taken from the deceased had the same effect. In earlier times such magic treatments used to be known all over the world. In Ingria, too, the magic with bonds was remembered even in the 1980s. They were sewn under the sleeve or collar of a man who was too quarrelsome; often, the bonds were taken along to the court (Mikkor 1995: 1902-1903). The Russians used to sew a thread pulled from a shroud into a belligerent man's clothes (Zelenin 1927: 322; Fursova 1983: 84). And Lithuanians used bonds to cure rheumatism (Nevskaia 1980: 249).

Church letters on a piece of paper are placed on the forehead of a deceased and an icon between its hands. Similarly to the cutlery, the icon was believed to protect against all evil. Such believes were widely popular among many peoples. Lutheran people used to place a hymnal on the chest of the deceased.

At the beginning of this century, the Mordvinians kept their dead home for one night only, and most often tried to bury the deceased already on the day it passed away (Hämäläinen 1930: 120; Harva 1942: 26), although it was considered against the church rules. Burial on the day after death was common in Povodimovo and Sabajevo even in the 1930s. On rare occasions it can happen even today, particularly if there is no need to wait for the relatives living further away and the dead body might decompose. Some people express a wish to be buried as soon as possible already before death. Although against the church rules, speeding up the burial 
was common elsewhere. Up to this century the custom of burying on the day of dying was followed by the Mari, the Perm-Komi, the Mansi people (Holmberg 1914a: 13; Holmberg 1914b: 20; Sokolova 1975: 165; Sokolova 1980: 134). Even the East-Slavonic peasants often buried their dead before three days had passed in order to get rid of the dead body that was in the way at the busy work period (Smirnov 1920: 30; Shein 1890: 535; 574). The Estonians used to do the same (Mikkor 1994a: 1266).

Generally, the peoples where Christianity had reached earlier delayed their funerals longer, while the Mordvinians have hurried their funerals for a relatively long period. This might have been the influence of their Muslim neighbouring people who always bury their dead as soon as possible. Some Georgian tribes who hurried their funerals were also thought to have been influenced by Muslim religion (Volkova \& Dzhavahishvili 1982: 148-149).

The hurrying often resulted in burying the apparently dead in suspended animation. Opening an old grave it was often seen that the deceased had turned around in the grave. Often the noise of those who woke from their death was heard. The accounts about the apparently dead were also universally known, and considering the hurried funerals there might have been some truth in them. Since the 1950s-1960s the dead are kept at home for two or three nights both in Sabajevo and Povodimovo.

Before the funeral the village people, mostly elderly women, come and pay their respects to the deceased, and wail over the coffin. The visitors bring along money which is cast into a glass jar on the table. The sum contributed ranged from a few dozens of kopecks to a couple of roubles, but the contribution itself mattered. In earlier times the Mordvinians who came to pay their respects to the dead used to bring food (Smirnov 1893: 537; Hämäläinen 1927: 131, Zelenin 1938: 90; Fedianovich 1990: 98), but today in Sabajevo and Povodimovo food is brought only to the funeral. The East-Slavonic people and the Estonians used to bring money or candles instead of food already in the previous century (Mashkin 1862: 81; Balov 1898: 88; Grünthal 1912: 344; Raadla 1939: 30; Richter 1979: 118).

In Sabajevo the collected money is used for buying two plates or bowls for the feast held forty days after someone's death, and a 
spoon for each expected guest. On the commemoration feast everyone eats with his/her own spoon from the common bowl. After the event the guests take the spoon home with them. The custom was more popular among the Russian Orthodox peoples (Smirnov 1920: 41; Zelenin 1927: 332; Kremleva 1980: 27); of course, certain parallels may be drawn with the Lutheran tradition to share food between all people attending the funeral or the commemoration feast to take it home. Even today, eating from common bowls or plates in everyday life was practised in both villages under discussion, particularly in Sabajevo.

During the nights the deceased is at home, all village women sit together in the house of mourning. A more knowledgeable woman, chitaatel or "the Reader" reads out psalms from the prayer book and all the others pray and wail. In Povodimovo some people remembered that before the chitaatels could be only old maidens, who were called "the Nuns", or monashke. Today the chitaatels may also be married or widowed women. Among the Russian Orthodox, but also other peoples, those attending death rituals or funeral ceremony had to be sexually pure, which explains why old maidens or widows were particularly favoured. Also, among other peoples, old maidens and widows were often called to wash the deceased (Balov 1898: 88, 89; Strogalshchikova 1986: 69) or to perform church commemoration services (Päss 1939: 240). Among the Setu people, a married woman could have no sexual intercourse for two weeks after the death of a close relative. The Christian church had its own rules for sexual activity during that period. The Arabs, however, employed women in menopause for undertakers (Granqvist 1965: 63).

After the spiritual part of the event, a dinner consisting of everyday food is served. During the fasting period and the fasting weekdays (Wednesday and Friday) fish and porridge of peas is served, avoiding meat, eggs and milk.

At night people take turns to hold a wake over the dead body, some of those attending the wake often lay down. Still, it is important to stay awake. The wake is believed to protect the deceased against evil spirits, known under their Russian name as pes or pjos. The evildoers might change the dead body with a monster, or push the body out of the bed. Similar beliefs are common among other peo- 
ples, as well. In Povodimovo, for example, an old maiden fell asleep during the wake over her mother's corpse and dreamt that her mother was grabbed from hands and feet and thrown to the floor. When she woke up she saw that nothing had happened, but after that incident she never had the courage to wake over someone else. In Sabajevo, the people who had fallen asleep during the wake and woke up, found the body on the floor. An Izhorian belief report confirms that a corpse which has fallen from the bench was thought to be possessed by an evil spirit (Päss 1939: 254).

People in Sabajevo said that if someone happens to die in solitude, he/she will be protected against evil spirits and wild animals by God until he/she is found. After that the dead body must be constantly under a wake. The Estonians have believed that the soul of a person who dies alone is taken by the devil, or Vanapagan (Raadla 1939: 29). Nowadays the need for constant wake over a dead body is explained by the fact that the deceased is scared to be alone, or that the corpse needs to be protected against vermin. In Sabajevo and Povodimovo the wake was mostly hold by women, sometimes also by fathers and sons.

Right after someone's death, preparations for his/her funerals are made. During the pre-funeral period it is forbidden to do some works: washing floors, for instance, would "smirch" the deceased. The number of such restrictions in used to larger in Mordvinia, it was also forbidden to heat ovens and bake bread, so the family of the deceased ate food that was brought to them by relatives (Harva 1942: 22). Similar restrictions were known in many countries, also among the Setu and the Russians (Richter 1979: 117; Zelenin 1927: $325)$.

In July 1989, however, a Russian oven in a room where a dead body was laid was heated three times a day to bake bread in the village of Povodimovo. At the same time the temperature outside was $+30{ }^{\circ} \mathrm{C}$ in the shadow, while the temperature inside the charnel house must have been over $+50{ }^{\circ} \mathrm{C}$.

Then, how did they handle decomposing bodies? In Sabajevo a bag of salt was placed on the chest or under the chin of the dead body. Today, a piece of wire is winded around the corpse's finger, the other end of the wire is led through the window and stuck into the ground 


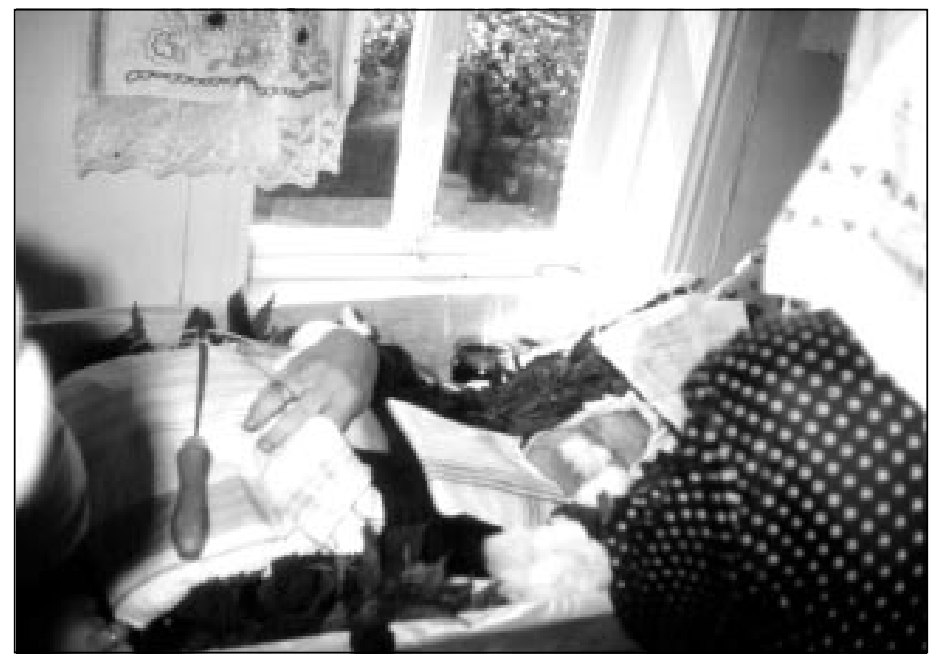

Photo 3. The deceased in coffin. The wire twisted around the finger is also twisted around the sickle lying on the stomach; the other end of the wire is in a vessel full of soil so there would be "ground connection". The deceased is surrounded by nettles, on the right beside the head is a glass jar with potassium permanganate solution. On the wall beside the window is a iconic scarf hanging, under which the deceased's spirit stayed for six weeks. July, 1989, in Povodimovo. Photo by Riin Alatalu.

for "ground connection". The same is done in Povodimovo, except the other end of the wire is stuck into a pot filled with soil under the bed of the deceased. An ancient custom of placing a sickle on the chest of the corpse (Zelenin 1938: 90) is still followed in Povodimovo. Under the bed they keep a bowl of cold water. One of the earliest and most common customs has been the placing of iron cutlery on the body or at its side (Eisen 1897: 50; Raadla 1939: 31), with the intention of keeping away evil spirits (Waronen 1898: 60; Chursin 1905: 66; Sartori 1910: 137). Soil and water have been used as means of preserving for the same purpose also elsewhere.

Today, the Mordvinians place potassium permanganate solution in a glass jar next to the dead body. On both sides of its neck, eggs are placed. While all the other measures mentioned above were used among many people, the use of eggs was relatively rare. The Izhorians placed an egg under the dead body's armpit to prevent it returning home (Mikkor 1995: 1907). On the Maluk islands, a raw egg was placed under the chin of the women who had died in child- 
birth: it was believed to prevent them from rising from the dead, as the deceased had to lie still to avoid breaking the egg (Clemen 1920: 15). Thus, eggs were used for magic purposes. Originally, eggs but also salt, soil, water and iron were associated with various magic concepts.

I also heard of using raw eggs in preserving the dead body from a young woman from Tartu, Estonia in the 1990s. Also, the above described "ground connection" has been used both in Estonia and Russia (EA 213: 277-278, 315; Mikkor 1994a: 1266).

The Erza, as well as the Izhorian and the Karelian people placed nettles on the clothes of the deceased (Kemppinen 1967: 29; EA 220: 107, 187). Today, the methods and means of preserving the dead are interrelated. In Povodimovo, for example, the wire winded around the corpse's finger was also wrapped around the sickle. Nowadays, the corpses are also treated with spirit, potassium permanganate and injections. At a funeral witnessed in July 1989 in Povodimovo, deceased had cotton stuck in its nostrils, apparently for practical reasons. But similarly to the custom of covering the eyes of the deceased, some peoples used to cover its nostrils with money or pieces of cloth to prevent the soul's return to the body. The Russians and Sami used to place a piece of cloth or money on the nostrils (Zelenin 1915: 663; Stora 1971: 219), whereas the Arabs filled all the cavities in a body with cotton (Granqvist 1965: $67)$.

\section{PLACING THE DEAD IN THE COFFIN. THE FUNERAL}

Today, the body is placed in the coffin, or kandelaaz at the morning of the burial day. Before it was done later during the day when the procession was halfway to the funeral (Harva 1942: 29).

Below I will describe a modern ceremony of placing the dead in the coffin in Povodimovo. Bringing the coffin in the chamber is accompanied by wailing. A monashke or a chitaatel reads out canon psalms and sings chorals. Then she consecrates the coffin by sprinkling it thrice with a birch whisk immersed in holy water (svjatoi vjäd). Then she goes with a candle three times around the coffin and crosses three times over the coffin. Then the body is laid in the 
coffin by the distant male relatives. The ritual is very characteristic to the Russian Orthodox peoples (Mahler 1935: 652-653; Shein 1890: 529, 572). The church funeral traditions characteristic to the Russian Orthodox religion rooted in Mordvinia only at the end of the 19th century (Fedianovich 1990: 99). In the fear of Soviet authorities the ceremony was not performed for a while, but is now held in esteem once again. As all the churches in the vicinity have been destroyed, then from where do they get holy water? It is believed that on the Twelfth Day, or the Epiphany (den kreshenja) the water in all wells, rivers and other bodies of water is holy, so it is hoarded for the whole year. A couple of jars containing holy water could be found in every household (EA 218: 288). The EastSlavonic people used to do the same (Animelle 1854: 229).

Similarly to other peoples, the Mordvinians used to send their dead off with generous gifts by placing clothes, food, tools, money and things for pleasure into their coffins (Smirnov 1893: 537, 538; Hämäläinen 1927: 130; Hämäläinen 1930: 119; Zelenin 1938: 91; Harva 1942: 26). Today, a handkerchief is placed in the coffin under the right arm of the dead body, and a church letter to the forehead and in the left hand. The church letter is sometimes called "the passport". A small icon is placed in the hands of the deceased, but this is taken from the coffin before the burial, as it is considered a sin to bury it. Lutheran peoples, however, used to bury prayer books and hymnals with the dead (Varjola 1980: 120; Raadla 1939: 34-35; Mikkor 1994a: 1484).

Burying the dead with other objects, like money, for example, was also considered a sin. At a funeral I witnessed in 1989 in Povodimovo, church letters were taken from the deceased right before the coffin was put in the grave, while the towel and the bonds used to tie its limbs were buried with it. A man in Povodimovo who was known for his stinginess had saved money all his life and sewn it in his grave clothes. He was buried with his money, but later his children opened his grave in order to get the money, and they saw a large snake at his chest. A similar account has been recorded from the Russians of Kostroma, which tells of a miser who had hidden his money inside the coffin pillow (Smirnov 1920: 47). In 1986 in Abkhazia in the Estonian village called Estonia I was told a story about an Abkhazian woman who had accidentally dropped 
her passport into her late husband's coffin, and he was buried with it. The woman searched for the passport everywhere, and eventually, her late husband appeared to her in a dream and told her to open his grave and take the passport from his coffin, but forbade her to look at him. The grave was opened and two large snakes were seen sucking on his chest.

The tradition of placing things in the grave had become quite rare among the Mordvinians by the 1920s (Fedianovich 1990: 113), which might be explained by the influence of the Russian Church. The few things that are placed in the coffin today are most characteristic to the Orthodox peoples.

The funerals are held at any time, except for the Easter. Before the noon of the funeral day about 40-60 relatives, acquaintances and neighbours of the deceased gather into the house of mourning. In Sabajevo the guests are not invited, while in Povodimovo they generally are. The funeral guests wear clothes similar to everyday clothes. In both villages I was told that the female relatives of the deceased wear a black scarf on their head as a sign of mourning, but on the funeral I happened to witness in Povodimovo everyone was wearing a white scarf. The guests bring food and money; in Povodimovo men also brought a bottle of vodka. The custom of taking food to the funeral used to be very popular among many peoples. Gradually, taking the food was replaced with taking the money, but soon even that was forgotten. For example, in the Võru region of Estonia food was taken to the funeral till the present day (Lang 1981: 49, 50). In some regions of Russia the custom of taking food to the funeral was substituted with taking money and candles already in the middle of the last century (Animelle 1854: 211; Mashkin 1862: 81; Balov 1898: 88).

The money (the sum ranging from a few dozen kopecks to a couple of roubles) was dropped in a glass jar on a window sill, and the food was placed on the table in the room of the deceased. The gifts were given to an elderly woman who placed them on a table. In Povodimovo funeral guests used to bring a bowl with a larger pie mostly with apple, cabbage or mushroom stuffing placed on three or four smaller cakes. Nowadays, every woman takes a large rounded scones, sweets, pies, ginger-breads and grits to the funeral. Two or more boiled eggs are placed on the grits in a bowl. In the 


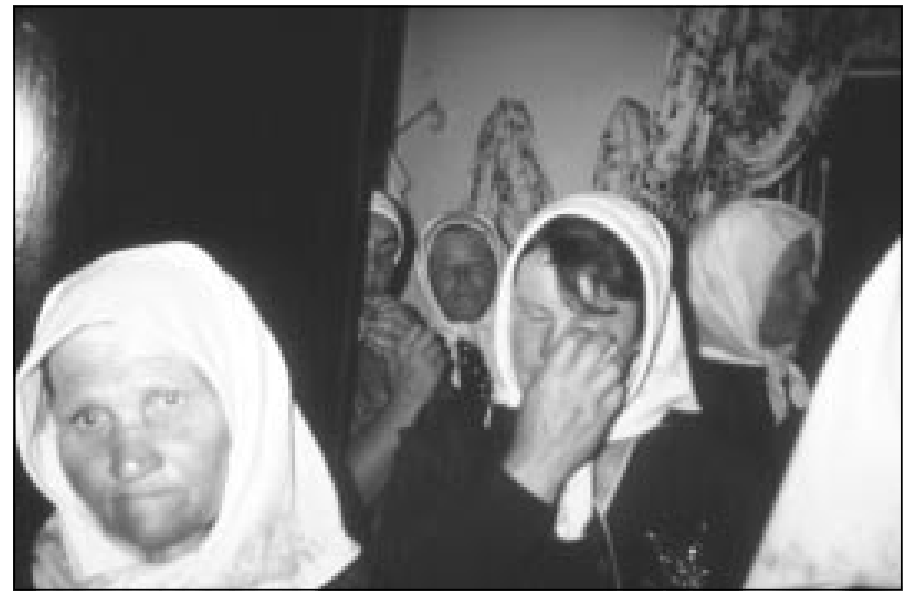

Photo 4. In both villages it was argued that female relatives of the deceased wear a black scarf as a sign of mourning; however, on the funeral I attended in Povodimovo, all scarfs were white. July, 1989, in Povodimovo. Photo by Riin Alatalu.

neighbouring Mordvin village Kabajevo only a candle is brought to the funeral.

Before, funeral guests in Sabajevo used to bring four smaller cakes, now they take two large wheat scones. The scones are put on top of each other and two boiled eggs and an even number of sweets between them. Thus, in Sabajevo and Povodimovo the custom of taking food to the funerals has retained its original form for a relatively long period. In summers, flowers are taken to the funeral of younger people.

Most of the funeral guests are elderly women, who usually participate in the leave-taking rituals. Men go to the cemetery to dig the grave. Women wail in the charnel chamber and a chitaatel reads out psalms.

Sometimes something hot, like a wheat or rice porridge and soup is served to the funeral guests before taking the deceased to the cemetery in Sabajevo. The food is also served to the deceased. In Povodimovo funeral guests eat snacks and sweets only. 
When the pasledni stol is finished, all the closer relatives are gathered around the coffin where they kneel with bowed heads and cross themselves. The person who washed the deceased walks around them and scrapes copper from a five-kopeck copper coin over everyone's head, a part of the leave-taking ritual. The scraping of a copper coin used to be very common in Mordvinia: it was performed while taking the funeral food from the guests, putting the deceased to the grave, over the clothes of the deceased and later also after the pre-funeral dinner over the guests' heads (Zelenin 1915: 974; Paasonen 1939: 502, 504; Harva 1942: 22, 23). U. Harva has assumed that this ritual is clearly borrowed from the Russians, as the custom is not common among other Finno-Ugric peoples. At the same time he makes a reference to Shein, a specialist in Belorussian folklore (Shein 1890: 534, 535; Harva 1942: 22). In fact, the custom was not that common among the Belorussians and the author of the current article has not heard of other East-Slavonic analogues to the tradition.

The deceased is taken outside at high noon, whereas the coffin remains open. At a funeral witnessed in 1989 in Povodimovo, the coffin was abruptly lifted up and hit against the doorjamb on its way out. The pallbearers were usually male relatives of the de-

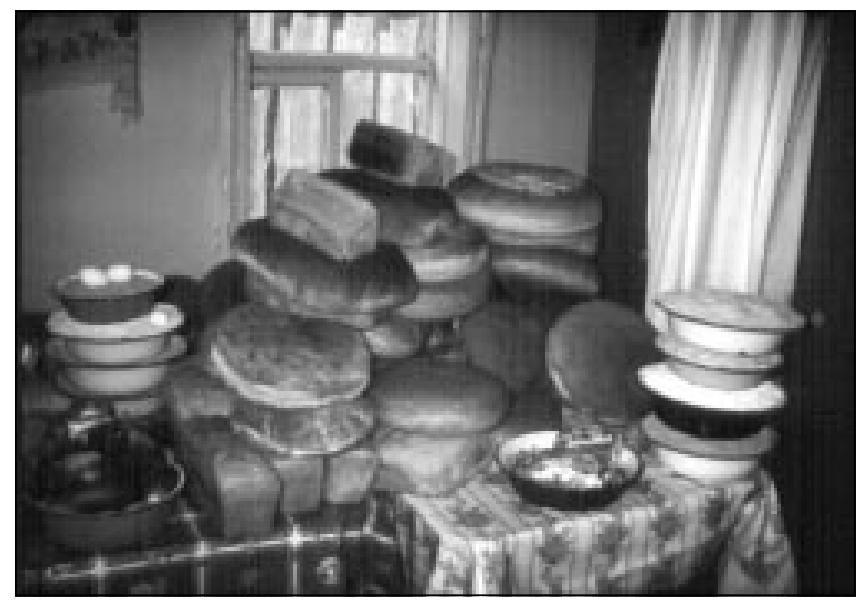

Photo 5. Gifts were received by an older woman who placed them on a table. Povodimovo, July 1989. Photo by Riin Alatalu. 
ceased, whereas the parents were not allowed to bear their children, and vice versa so that the deceased would not be offended. In Povodimovo, a young girl was carried by girls and a young man by young men. Nowadays, the coffin is carried on shoulders and the number of pallbearers is four to six. Earlier the coffin was carried on a bier called noosilka (in Sabajevo) or kandoma palkat (in Povodimovo). The bier consisted of two longer bars with two ropes tied between their ends. The coffin was placed on the ropes and the bier lifted to the shoulders of the pallbearers. Such biers were used in Sabajevo even in the 1940s. After burial the bier was left to the graveyard and elderly people used them for firewood. In Povodimovo women, young men and girls were carried on long narrow strips of hempen linen. (The Russians used pieces of cloth for the funerals of the more important persons (Smirnov 1920: 34), but the Estonians used it at the funerals of young girls (Lang 1981: 67)).

Nowadays, the coffins of younger people are carried on ropes.

People in Povodimovo remembered that if a sick person wanted to get rid of his disease, he had to walk through from under the bier when the coffin was lifted on it. Literary sources suggest that the same procedure had to be followed by the relatives of the deceased so as to get rid of the fear for the dead (Fedianovich 1975: 408; Fedianovich 1990: 114). The custom was known also among other peoples (Shein 1890: 515; Strogalshchikova 1986: 78; Zelenin 1915: 909).

In earlier times the pallbearers were not paid, but today a handkerchief similar to that of the grave diggers is tied around their arm.

Directly after taking the coffin out of the chamber, the bench or the table on which the deceased was laid is washed with water, and the floor is wiped with a sweeping brush in Povodimovo. In Sabajevo a hatchet, a knife or other piece of iron cutlery is placed on the spot where the dead body was laid to prevent the deceased from returning home, or protect the family from another death or keep the relatives from mourning too long. Before, the Mordvinians used to do the same at the place of the death. 
The aforementioned preventive magic procedures used to be known all over the world. Cutlery was placed on the site of the deceased in many countries (see Zelenin 1927: 324; Loorits 1932: 190; Mahler 1935: 654; Juvas \& Reponen 1939: 287; Talve 1979: 189). In Estonia, for example, a nail was hit in a threshold or the place where the dead body was laid (Wiedemann 1876: 316; Jung 1879: 112; Boecler \& Kreutzwald 1854: 69). The Veps placed there a poker or an aspen log (Strogalshchikova 1986: 72), the Karelians put charcoal, hot ashes, an iron object, etc. (Konkka 1985: 58), the Setu a porridge spoon (Loorits 1949: 74), the Georgians a stone (Chursin 1905: 71).

After the coffin is carried out of the house, it is placed on a bench in the yard. Relatives wail and pay their respect to the deceased. In Povodimovo, the bench was made directly before carrying the coffin out of the house. Outside the church texts and the sickle is taken out of the coffin.

Only the closest relatives go to the graveyard to bury the dead (kulõn kalmama), the rest of the guests start with funeral feast.

The coffin is either carried to the graveyard, or taken on a truck. The truck box is decorated with green boughs. The closest relatives sit in the truck box around the coffin and wail. When walk-

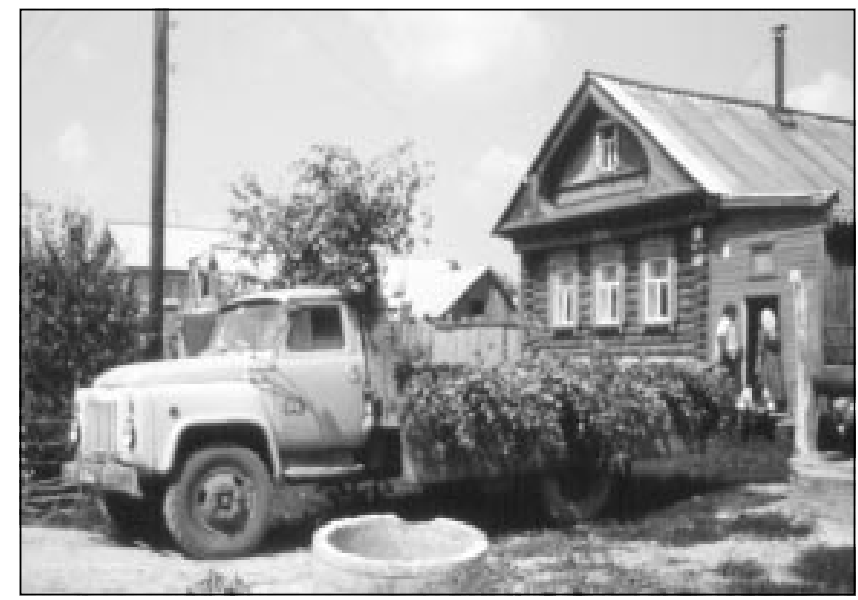

Photo 6. Truck box decorated with branches. July 1989, in Povodimovo. Photo by Riin Alatalu. 
ing, the funeral procession was the following: the coffin lid was followed by the coffin, then came the funeral guests and then the cross. At the 1989 funeral in Povodimovo the truck with the coffin and closest relatives drove in front, and about thirty-five women and five grave-diggers walked behind. Some grave-diggers waited already at the graveyard. The funeral procession ended with a tractor with a dozen or so grave-diggers and a large iron cross in the box. Birch boughs were thrown from the funeral truck to the road, the tradition has been followed since the 1950s. The boughs are supposed to help the deceased find its way back home to the commemoration feast. In Sabajevo boughs are sometimes thrown on the road only at the young people's funerals. Casting the boughs on the way of the funeral procession was common among many peoples, whereas the origin of the custom is unclear.

Several rules had to be followed when a funeral procession happened to pass. In Sabajevo it was forbidden to cross the road near a

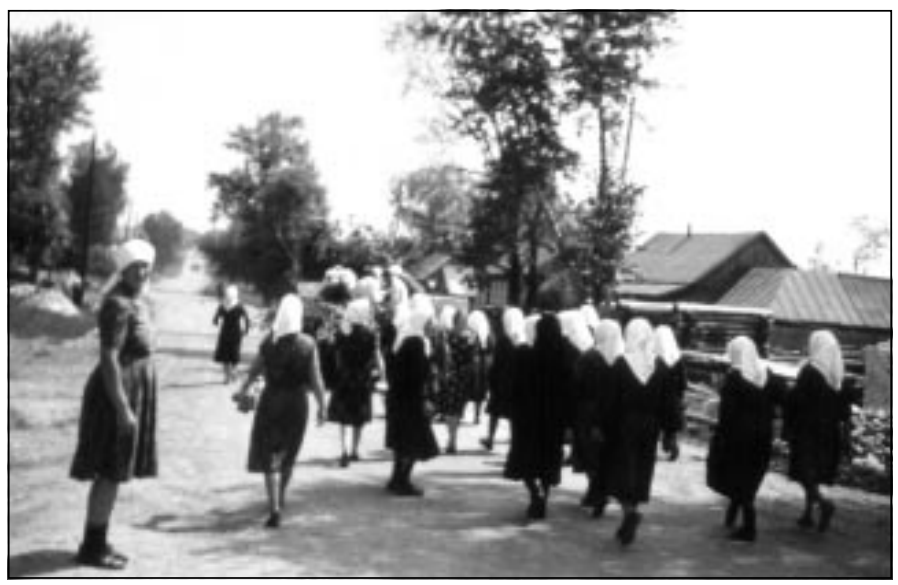

Photo 7. Only those closest to the deceased go to the funeral to bury the body (kulonn kalmama); the rest start with the funeral feast. In Povodimovo, July 1989, the truck carrying the coffin and relatives led the procession, followed by women and gravediggers on foot. Photo by Riin Alatalu.

funeral procession or a person might have fallen ill. Who still happened to do it, had to ask for forgiveness from the deceased. Looking at a funeral procession through a window was also considered 
dangerous; then it was best to leave the house, make a cross sign and pray. Those who happen to meet a funeral procession usually stop and men uncover their heads. The first person met at a funeral procession is given a bag of bread, apples, eggs, sweets and a rouble.

In Povodimovo, the first person that meets the funeral procession is given a simple white towel without embroidery called nardama and some food. It is given by the elderly woman who walks in front of the procession. She is called ikelev kuchoma. The custom is most popular among the East-Slavonic peoples (Balov 1898: 89; Zavoiko 1914: 94; Smirnov 1920: 33; Kremleva 1980: 25; Maslova 1984: 95), but also among the Finno-Ugric Orthodox peoples (Lukkarinen 1914: 8; Strogalshchikova 1986: 73). Up to the present day the Estonians of Lutheran Vorru region follow the custom of giving the first man met on a procession a bottle of vodka and a woman a box of chocolate or a cake (EA 213: 342).

If the number of people met on a procession or following it was larger, it was believed to be a sign of a coming death in the family.

In Povodimovo the funeral procession stopped while passing the houses of relatives. The same custom was followed by the Votes (Haavamäe 1934: 442). But the Estonians, Karelians and Germans used to make a stop at the farm and village borders, crossroads, etc (Sartori 1910: 148; Juvas \& Reponen 1939: 289).

A small table covered with sweets, apples, cookies and other snacks, also with vodka and wine was set up at every stop.

Some funeral guests already wait for them at the graveyard (kalmozer). The grave - kalma - is dug at the morning of the same day, so that it would not stay open overnight and the evil spirit could not enter it. The grave is dug by eleven to twenty-five men, usually the relatives of the deceased. It is forbidden to dig the grave for one's parents or children, thought. In earlier times the gravediggers were served food at home before starting the work, today they take their food and drink to the graveyard. Digging the grave helped to predict the sex of the next to die. At the spot where the spade is first driven in the ground a coin is tossed, heads denoting a man and tails a woman. An old woman asked to be told where she 


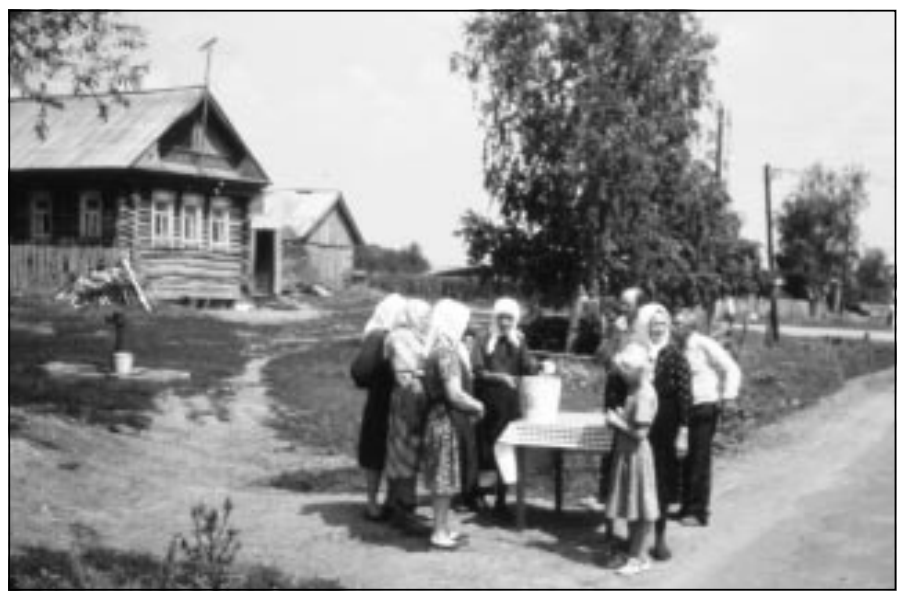

Photo 8. In Povodimovo, the funeral procession made a stop when passing houses of the deceased's relatives. In every stop, a small table with candies, apples, biscuits and other snacks as well as wine and vodka was set up beside the road for those participating the funeral. July 1989. Photo by Riin Alatalu.

was going to die that year. The same day on her way home from the graveyard she fell from a bridge to ice and was found dead the next morning. When the grave was finished, one of the diggers went home to tell the others about it, while all the other diggers waited at the graveyard. But if the grave diggers had to bear the coffin as well then at least one man stayed behind at the cemetery to protect the grave against evil spirits. Such beliefs concerning the grave were common for other Orthodox peoples as well (Paulaharju 1924: 103; Kremleva 1980: 25; Karely 1983: 148; Konkka 1985: 57; Mikkor 1995: 1912).

At the cemetery the coffin is placed next to the open grave and the funeral guests wail. Before lowering the coffin to the grave an icon is taken from the deceased one's hands, and nettles from the coffin. The face of the deceased is covered with a sheet from under its chin, and its whole body is covered with a shroud. First handfuls of earth are dropped on the shroud. Usually, the coffin is lowered into the grave by ropes. In summer 1989 in Povodimovo the open coffin was passed on to two men in the bottom of the grave, who then cast a few handfuls of earth to the open coffin and then closed it. The wide grave was two metres deep. The earlier literary sources about 
Mordvin traditions do not mention the coffin's passing to someone in the grave. The custom has been mentioned in the material concerning the Veps (Strogalshchikova 1986: 74), and it used to be followed in Estonia as well (ERM 165, 22/3 (70) < Jõelähtme; AES Kadrina 1932; RKM II 82, 585, (65) < Torma). Some Caucasian Estonians have most probably adopted the custom from the local Caucasian people (Mikkor 1992: 177).

All funeral guests threw one handful of earth in Sabajevo and three in Povodimovo to the deceased. The custom is believed to relieve fear of the dead and to forget him faster. It was also a tribute. On rare occasions copper coins have been cast into the grave in Sabajevo to buy the deceased a place in the other world. At the same time it is considered a Russian custom. In Povodimovo, however, casting money to the grave was considered a sin. In earlier times the Mordvinians used to cast both money as well as food into the grave (Butuzov 1893: 486; Smirnov 1893: 542). It is possible also that the custom of throwing money into the grave was not popular everywhere in Mordva. The Belorussians, for example, are known to have thrown money to the grave only if the new grave was dug on the old one with bones still inside. Then the place had to be "bought" from the former deceased (Shein 1890: 559).

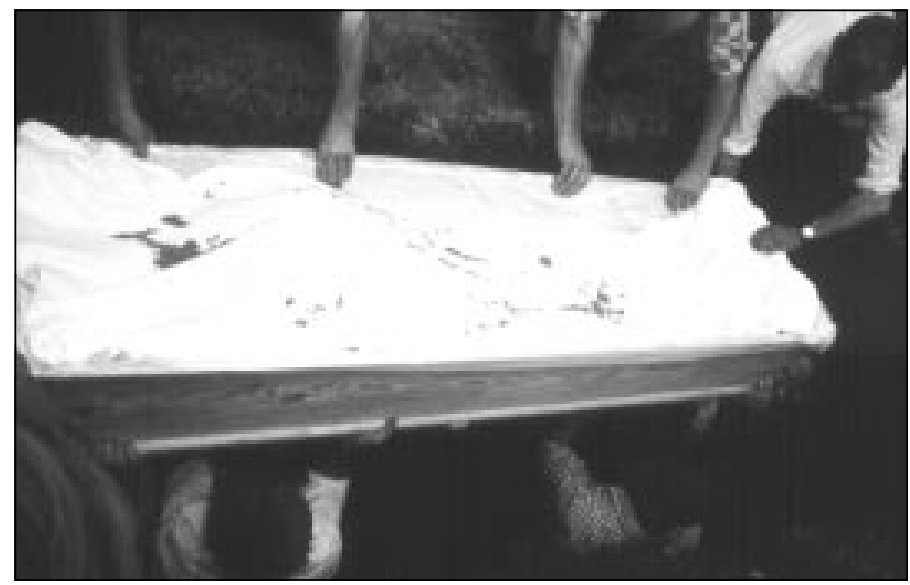

Photo 9. In Povodimovo, summer 1989, the opened coffin was received by two men standing in the bottom of the grave. The grave was wide and two meters deep. Photo by Riin Alatalu. 
In Sabajevo it is said that the deceased cried when the coffin was lowered into the grave, but it is heard only by few. The one who hears it must prepare for the worst. Once a child was buried. When the grave was closed a young girl went to the cross and heard the dead child calling its mother thrice. The same year the girl's mother died.

Usually, the grave was closed fast. In Povodimovo a small hole symbolising a window was made on the burial mound. The same was done by the Livonians, as well as the Setu (Loorits 1932: 195; Väisänen 1924: 219).

In Sabajevo, after closing the grave a man carrying a spade and a woman carrying a towel went three times around the grave to keep the dead in the grave. But the Germans, for example, all funeral guests had to go around the grave (Sartori 1910: 151).

The mounds of younger people are decorated with flowers and wreaths. At one time, the people in Sabajevo used to surround the grave with a large garland of boughs. But since a relative had a dream about the deceased who had told him that he got stuck in the wire around the garland, they are no longer used. About two metres high wooden cross made of squared logs was placed at the foot of the grave, and the family mark of the deceased carved into it. In Sabajevo the tradition was followed to the recent times; to-

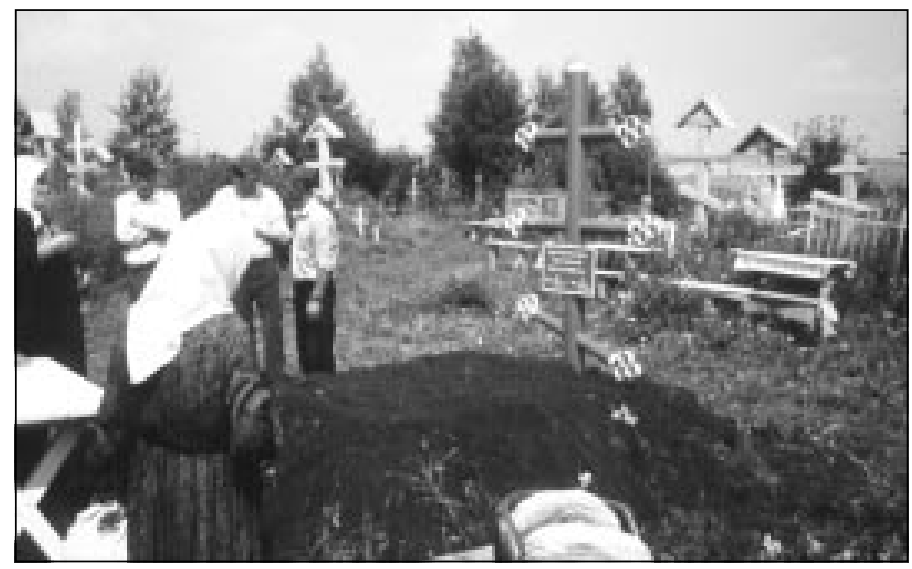

Photo 10. The fresh grave. Photo by Riin Alatalu, 1989. 
day, the crosses have also texts carved in them. In today's Povodimovo, however, iron crosses are used.

The grave diggers were generally not rewarded for the work, but nowadays they are given handkerchiefs, towels and shirts. In Sabajevo it is done only at the funerals of young people. And, apparently, under the Russian cultural influence.

After closing the grave food is served to the funeral guests at the cemetery. In Sabajevo the grave is covered with towels where food is placed. In Povodimovo the food was placed on a smaller table next to the grave, and people eat standing up. Thus, we can see how the ritual feast is becoming isolated from the grave, the original commemoration place. The Orthodox peoples, like the Estonian Setu (Väisänen 1924: 219; Loorits 1949: 84) and the Finnish Karelians (Varjola 1980: 122) have retained the heathen tradition of eating on the grave longer than others. Mostly Lutheran peoples substituted it with serving food next to the grave or behind the graveyard's gate (Reiman 1915: 158; Eisen 1919: 42), or sharing it with the poor (Eisen 1897: 26; Reiman 1915: 160; Raadla 1939: 72 ).

The table is covered with pies, sandwiches, apples, sweets, fish, eggs, bread, onions, meat, vodka and kvass. During the fast or the specific fasting days no meat or eggs are served. In Sabajevo porridge is served as well, most often it is made of wheat, whereas in Povodimovo, a pot of honey on the table was a must. In Sabajevo it was forbidden to use knives: bread and pies had to be divided in pieces using hands only. Also, the number of pies, scones and other food had to be even. This rule known also among other peoples was later extended to the feast held at home after the funeral as well as the commemoration feast (Lukkarinen 1914: 10; Zelenin 1934: 14; Kremleva 1980: 27). Cutlery was believed to harm the souls participating in the feast. Among many peoples, the use of cutlery after someone's death was forbidden during the period the soul was thought to be around (Frazer 1974: 299). Even in the 1980s Estonia I met the belief that one must not use the scissors near the grave (Mikkor 1999: 20, 24).

At the graveyard food is shared between the funeral guests to take home as well. 
After the burial everyone had to return to the house of mourning to wash their hands and eat something. In earlier times they had to wash their faces, too, a ritual which functions as a clearly preventive magic procedure. Today many of the guests return to their homes right after the funeral ceremony. Others, however, still believe that it is necessary to participate in the funeral feast at the house of mourning lest the deceased might stay hungry.

Funeral food consisted usually of meat soups, eggs, (mostly wheat) porridge. During the fast cabbage or pea soup and fish was served. Fruit jelly is served for dessert. The grave diggers could eat meat also during the fasting period.

\section{CONCLUSION}

Most of the customs and beliefs discussed in the article are either universal or characteristic only to the Orthodox peoples. The survival of some customs (restrictions concerning feather pillows, taking food to the funeral, etc) during a longer period of time is truly remarkable. The hurried burials might be considered of heathen origin but also an influence of Muslim neighbours. Different religious layers and concepts are interrelated in the somewhat controversial Orthodox customs, such as placing a glass of water and food next to the deceased.

Several customs in Sabajevo, like paying to the undertaker or casting boughs on the road of a funeral procession are still making their way to the tradition, whereas they are most common at the funerals of younger people. In Povodimovo such "Russian customs" were adopted earlier. Russian influence appears to be relatively strong both in material as well as spiritual culture.

\section{References}

\section{Sources}

$\mathrm{EA}=$ The Ethnographic Archives of the Estonian National Museum

EA 213: 251-346. Mikkor, M. 1989. Inimese sünni ja surmaga ning abiellumisega seotud tavad ja uskumused Laiuse, Torma ja Urvaste kihelkondades. 
EA 218: 64-159. Mikkor, M. 1988. Etnograafilisi materjale inimese elutähtpäevadega seotud kombestiku ning peremärkide kohta Mordvast Kochkurovi raj. Sabajevo külast.

EA 218: 245-370. Mikkor, M. \& Alatalu, R. 1989. Teateid ersa mordvalaste perekonnakombestiku, kalendritähtpäevade, asustuse, elatusalade ja muu eluolu kohta (Mordva ANSV Kochkurovi raj. Sabajevo k. ja Dubjonki raj. Povodimovo k.).

EA 220: 96-201. Mikkor, M. 1988. Inimese elutähtpäevadega seotud kombestikust isuritel ja soomlastel.

AES = folklore collection of the Academical Association of Mothertongue.

ERA $=$ folklore collection of the Estonian Folklore Archives, 265,098 pp., basically 1927-1944.

$\mathrm{ERM}=$ folklore collection of the Estonian National Museum, 9,398 pp., 1815-1925.

$\mathrm{RKM}=$ folklore collection of the Estonian Folklore Archives of the Estonian Literary Museum of the EstonianAcademy of Sciences, by January 1, 1995 445,780 pp., basically since 1945 .

\section{Publications}

Abramov, I. 1907. Pishcha pokoinikam u sovremennykh malorossov. Zhivaia Starina, vyp. III, otd. V, p. 29.

Animelle, N. 1854. Byt belorusskikh krestian. Etnograficheskii Sbornik, izdavaiemyi Imperatorskim Russkim Geograficheskim Obshchestvom, vyp. II. Sankt-Peterburg, pp. 111-268.

Balov, A. 1898. Bolezni i ikh lechenie; smert, pokhorony i pominki; zagrobnaia zhizni. Etnograficheskoe Obozrenie, 4, pp. 86-92.

Boecler, J. W. \& Kreutzwald, Fr. R. 1854. Der Ehsten abergläubische Gebräuche, Weisen und Gewohnheiten von J. W. Boecler. Mit auf die Gegenwart bezüglichen Anmerkungen beleuchtet von Dr. Fr. R. Kreutzwald. St. Petersburg.

Bogoslavski, P. 1924. Materialy po narodnomu bytu, fol'kloru i literaturnoi starine. Permskii kraievedcheskii sbornik, vyp. I. Perm', pp. 7083.

Butuzov, F. 1893. Iz byta Mordvy sela Zhivaikina Zhadovskoi volosti Karsunskago u. Simbirskoi gub. Izvestia Obshchestva Arkheologii, Istorii i Etnografii pri Imperatorskom Kazanskom Universitete, t. XI, vyp. V. Kazan', pp. 485-488.

Chursin, G. 1905. Narodnye obychai $i$ verovania Kakhetii. Zapiski Kavkazkago Otdela Imperatorskago Russkago Geograficheskago Obshchestva, kn. XXV, vyp. 2. Tiflis.

Chursin, G. 1956. Materialy po etnografii Abkhazii. Suhumi. 
Clemen, C. 1920. Das Leben nach dem Tode in Glauben der Menschheit (Aus Natur und Geisteswelt, B. 544). Leipzig \& Berlin.

Dzhanashvili, M. 1893. Kartvelskia poveria. Sbornik Materialov dlia Opisania Mestnostei i Plemen Kavkaza, vyp. 17. Tiflis, pp. 144-173.

Eisen, M. J. 1897. Kodukäijad. Katse nende loomu seletuseks ja 40 juttu surnute hingede ilmumisest. Narva.

Eisen, M. J. 1919. Eesti mütoloogia. Tartu.

Fedianovich, T. 1975. O sovremennoi semeinoi obriadnosti mordvy sel'skoi mestnosti. Voprossy finno-ugrovedenia. Vyp. 6. Saransk, pp. 404409.

Fedianovich, T. 1990. Pokhoronnye i pominal'nye obriady mordvy. Bytovaia kul'tura mordvy. Trudy. Nauchno-issledovatel'skii institut iazyka, literatury, istorii i ekonomiki pri Sovete Ministrov Mordovskoi ASSR. Vyp. 100. Saransk, pp. 96-125.

Frazer, J. G. 1974. The Golden Bough. A Study in Magic and Religion.

Fursova, J. 1983. Zhenskaia pogrebal'naia odezhda russkogo naselenia Altaia. Traditsii $i$ innovatsii v bytu $i$ kul'ture narodov Sibiri. Novosibirsk, pp. 73-87.

Granqvist, H. 1965. Muslim Death and Burial. Commentationes humanarum litterarum. Tomus XXXIV, Nr. 1. Helsinki.

Grünthal, A. 1912. Surnute austus. Eesti Kirjandus, pp. 342-348.

Haavamäe, A. 1934. Vatjalaisia kuolemaan ja hautaamiseen liittyviä tapoja ja uskomuksia. Virittäjä, pp. 435-446.

Haavio, M. 1934. Piirut. Suvun vainajien juhla. Kotiseutu, pp. 85-91.

Harva, U. 1935. Varsinais-Suomen henkistä kansankulttuuria. Varsinais-Suomen historia III:1. Porvoo.

Harva, U. 1942. Mordvalaisten muinaisusko. Suomensuvun uskonnot 6. Porvoo \& Helsinki.

Holmberg, U. 1914a. Cheremissien uskonto. Suomensuvun uskonnot 5. Porvoo.

Holmberg, U. 1914b. Permalaisten uskonto. Suomensuvun uskonnot 4. Porvoo.

Hämäläinen, A. 1927. Kuolemantapaukseen liittyvistä mordvalaisten tavoista. Kalevalaseuran Vuosikirja, 7, pp. 127-141.

Hämäläinen, A. 1930. Beiträge zur Ethnographie der Ostfinnen. Suomalais-ugrilaisen Seuran Aikakauskirja XLIV, 1. Helsinki, pp. 1-160.

Iashchurzhinski, H. 1898. Ostatki iazychestva v pogrebal'nykh obriadakh Malorossii. Etnograficheskoe Obozrenie, 3, pp. 93-95.

Itkonen, T. 1948. Suomen lappalaiset vuoteen 1945, I. Porvoo.

Jung, J. 1879. Eesti rahva vanast usust, kombedest ja juttudest. Kodumaalt, nr. 6. Tartu.

Juvas, M. \& Reponen, A. 1939. Kuolemaan liittyviä tapoja ja uskomuksia. Kansatieteellisiä muistiinpanoja Ilomantsin itäkylistä. Kansatieteellinen arkisto III. Forssa, pp. 283-293. 
Karely 1983 = Karely Karel'skoi ASSR. Petrozavodsk.

Kemppinen, I. 1967.Haudantakainen elämä karjalaisen muinaisuskon ja vertailevan uskontotieteen valossa. Karjalan Tutkimusseuran Julkaisuja 1. Helsinki.

Konkka, U. 1985. Ikuinen ikävä. Karjalaiset riitti-itkut. Suomalaisen Kirjallisuuden Seuran Toimituksia 428. Helsinki.

Kotliarevski, A. 1891. O pogrebal'nykh obychaiakh iazycheskikh slavian. Sochinenia A. A. Kotliarevskago, t. III. Sbornik Otdelenia Russkago Iazyka $i$ Slovestnosti Imperatorkoi Akademii Nauk, XLIX. SanktPeterburg, pp. 1-296.

Kremleva, I. 1980. Pokhoronno-pominal'naia obriadnost' russkogo naselenia Permskoi obl. Polevye issledovania Instituta etnografii, 1978. Moskva, pp. 21-30.

Kulikovski, F. 1890. Pokhoronnye obriady Obonezhskago kraia. Etnograficheskoe Obozrenie, kn. IV, No. 1, pp. 44-60.

Lang, M. 1981. Endisaegsed matusekombed Ida-Eestis. Diplomitöö Tartu Ülikooli lähiajaloo kateedris. Tartu.

Lenchevski, L. 1899. Pokhoronnye obriady i poveria v Starokonstantinovskom u. Volynskoi gub. Kievskaia Starina 1899 iul', t. LXVI, pp. 70-78.

Loorits, O. 1932. Der Tod in der livischen Volksüberlieferung. Õpetatud Eesti Seltsi toimetised XXVI. Tartu, pp. 170-200.

Loorits, O. 1949. Grundzüge des estnischen Volksglaubens, I. Lund.

Lukkarinen, J. 1914. Inkeriläisten vainajainpalveluksesta. Kansatieteellisiä tutkielmia. Suomalais-ugrilaisen Seuran Toimituksia XXXV:7, Helsinki, pp. 1-18.

Luzgin, A. \& Mezin, P. 1986. Odezhda. Sotsialisticheskii byt mordovskogo sela. Saransk, pp. 118-127.

Mahler, E. 1935. Die russische Totenklage. Ihre rituelle und dichterrische Deutung (mit besondere Berückrichtung des grossrussischen Nordens). Leipzig.

Malia, J. 1982. Odezhda abkhazov. Odezhda $i$ zhilishche abkhazov. (Materialy dlia istoriko-etnograficheskogo atlasa Gruzii.) Tbilisi, pp. 5126.

Mamaladze, G. 1893. Narodnye obychai i poveria guriitsev. V dvukh chastiakh. Sbornik Materialov dlia Opissania Mestnostei i Plemen Kavkaza, vyp. 17. Tiflis, pp. 15-123.

Manninen, I. 1957. Die Kleidung. Kansatieteellinen Arkisto 13. Helsinki, pp. 53-178.

Mashkin 1862. Byt krestian Kurskoi gubernii Oboianskago uiezda. Etnograficheskii Sbornik, izdavaiiemyi Imperatorskim Russkim Geograficheskim Obshchestvom, vyp. V. Sankt-Peterburg, pp. 1-119.

Maslova, G. 1984. Narodnaia odezhda v vostochno-slavianskikh traditsionnykh obychaiakh i obriadakh XIX - nachala XX v. Moskva. 
Mikkor, M. 1992. Kaukaasia eestlaste matusekombestikust. Eesti Rahva Muuseumi Aastaraamat 39. Tartu, pp. 167-188.

Mikkor, M. 1994a. Kaukaasia eestlaste surmakujutelmadest. Akadeemia, nr. 6, pp. 1234-1267, nr. 7, pp. 1281-1496.

Mikkor, M. 1994b. Surmaga seotud tavadest ersamordva külades Sabajevos ja Povodimovos. Eesti Rahva Muuseumi Aastaraamat XL. Tartu, pp. 153-189.

Mikkor, M. 1995. Soikkola isurite matusetavad. Akadeemia, nr. 6, pp. 1889-1927.

Mikkor, M. 1996. Linnud, loomad, ebaselge päritoluga hääled ja unenäod surmaennetena Kaukaasia eestlastel. Eesti Rahva Muuseumi Aastaraamat XLI. Tartu, 167-181.

Mikkor, M. 1998. Ersade sünnikombestikust Sabajevo ja Povodimovo külas. Eesti Rahva Muuseumi Aastaraamat XLII. Tartu, 53-78.

Mikkor, M. 1999. Sünni- ja matusekombestiku uurimisest linnas. About the Study of Birth and Funeral Customs in Towns. Maa ja linn. Eesti Rahva Muuseumi 40. konverents. Teesid. Tartu, 18-20, 21-24.

Mordovski $1990=$ Mordovskii narodnyi kostium. 1990. Saransk.

Nevskaia, L. 1980. Pogrebal'nyi obriad v Peliase (struktura i terminologia). Balto-slavianskie etnoiazykovye kontakty. Moskva, pp. 245254.

Paasonen, H. 1939. Mordwinische Volksdichtung. Herausgeben und übersetzt von Paavo Ravila. Suomalais-ugrilaisen Seuran Toimituksia LXXXI, 2. Helsinki.

Paulaharju, S. 1924. Syntymä, lapsuus ja kuolema: Vienan Karjalan tapoja ja uskomuksia. Kalevalaseuran Julkaisuja 2. Porvoo.

Pentikäinen, J. 1971. Marina Takalon uskonto. Uskontoantropologinen tutkimus. Suomalaisen Kirjallisuuden Seuran Toimituksia 299. Helsinki.

Päss, E. 1939. Death, burial and life beyond the grave with the Estonian Ingers and the Votes. Opptatud Eesti Seltsi Aastaraamat 1937, nr. II. Tartu, pp. 193-259.

Raadla,A. 1939. Eesti matusekommete ülevaade. Seminaritöö. Käsikiri Eesti Rahvaluule Arhiivis.

Reiman, H. 1915. Eestlaste matusekombed. Eesti Kultura IV. Jurjev, pp. 123-163.

Richter, J. 1979. Nekotorye ossobennosti pogrebal'nogo obriada setu. Sovetskaia Etnografia, No. 2. Moskva, pp. 116-128.

Rosenplänter, J. H. 1823. Ueber Kirchhöfe und Beerdigung der Todten, nebst einem Anhange den Pernauschen Kirchhof betreffend. Pernau.

Ränk, G. 1949. Das Heilige Hinterecke im Hauskult der Völker Nordosteuropas und Nordasiens. Folklore Fellows Communications 137, vol. LVII. Helsinki.

Sagaradze, M. 1899. Obychai i verovania v Imeretii. Sbornik Materialov dlia Opissania Mestnostei i Plemen Kavkaza, vyp. 26. Tiflis, pp. 1-46. 
Salmio, L. 1976. Kuolinhetken toimet Länsi-Suomessa. Kotiseutu, pp. $24-32$.

Samter, E. 1901. Familienfeste der Griechen und Römer. Berlin.

Sartori, P. 1910. Sitte und Brauch. Handbücher zur Volkskunde. Bd. 5. Leipzig.

Selirand, J. 1974. Eestlaste matmiskombed varafeodaalsete suhete tärkamise perioodil (11.-13. sajand). Tallinn.

Shangina, I. 1984. Prilozhenie. Obriadovaia odezhda vostochnoslavianskikh narodov v sobranii Gosudarstvennogo muzeia etnografii narodov SSSR. In: Maslova, G. Narodnaia odezhda v vostochnoslavianskikh obychaiakh i obriadakh XIX - nachala XX v. Moskva, pp. 156-213.

Shein, P. 1890. Materialy dlia izuchenia byta i iazyka russkago naselenia Severo-Zapadnago kraia. T. I, ch. II. Sbornik Otdelenia Russkago Iazyka i Slovestnosti Imperatorkoi Akademii Nauk. T. 51, No. 3. SanktPeterburg, pp. 1-708.

Smirnov, I. 1893. Mordva. Istoriko-etnograficheskii ocherk. Gl. 4. Izvestia Obshchestva Arkheologii, Istorii i Etnografii pri Imperatorskom Kazanskom Universitete, t. XI, vyp. 6. Kazan', pp. 452-564.

Smirnov, V. 1920. Narodnye pokhorony i prichitania v Kostromskom krae. Kostromskoe Nauchnoe Obshchestvo po izucheniu mestnogo kraia, vyp. XV. Vtoroi etnograficheskii sbornik. Kostroma, pp. 21-126.

Sokolova, Z. 1975. Novye dannye o pogrebal'nom obriade severnykh hantov. Polevye issledovania Instituta etnografii, 1974, pp. 165-174.

Sokolova, Z. 1980. Hanty i mansi. Semeinaia obriadnost' narodov Sibiri: Opyt sravnitel'nogo izuchenia. Moskva, pp. 125-143.

Stora, N. 1971. Burial Customs of the Scolt Lapps. Folklore Fellows Communications 210. Helsinki.

Strogalshchikova, Z. 1986. Pogrebal'naia obriadnost' vepsov. Etnokul'turnye protsessy v Karelii. Petrozavodsk, pp. 65-85.

Talve, I. 1979. Suomen kansankulttuuri. Historiallisia päälinjoja. Suomalaisen Kirjallisuuden Seuran Toimituksia 355. Helsinki \& Mikkeli.

Uibopuu, V. 1984. Meie ja meie hõimud. Peatükke soome-ugrilaste minevikust ja olevikust. Lund.

Varjola, P. 1980. Vainajan matkavarusteista. Kotiseutu, pp. 118-126.

Veletskaia, N. 1968. O nekotorykh ritual'nykh iavleniakh iazycheskoi pogrebal'noi obriadnosti. (K analizu soobshchenia Ibn-Fadlana o pokhoronakh "Russa".) Istoria, kul'tura, fol'klor i etnografia slavianskikh narodov. Moskva, pp. 192-212.

Vilkuna, A. 1989. Valkoinen liina, vainajan liina. Tavan takaa. Kansatieteellisiä tutkimuksia tapojemme historiasta. Jyväskylän yliopisto, etnologian laitos. Tutkimuksia 24. Jyväskylä, pp. 260-286.

Volkova, N. 1978. Etnicheskie protsessy v Gruzinskoi SSR. Etnicheskie i kul'turno-bytovye protsessy na Kavkaze. Moskva, pp. 3-61. 
Volkova, N. \& Dzhavahishvili, G. 1982. Bytovaia kul'tura Gruzii XIX$X X$ vekov: traditsii $i$ innovatsii. Moskva.

Väisänen,A. O. 1924. Syntymä, lapsuus ja kuolema. Setukaisten tapoja ja uskomuksia. Kalevalaseuran Vuosikirja, 4, pp. 193-223.

Waronen, M. 1898. Vainajainpalvelus muinaisilla suomalaisilla. Suomalaisen Kirjallisuuden Seuran Toimituksia 87. Helsinki.

Wiedemann, F. J. 1876. Aus dem inneren und äusseren Leben der Ehsten. St. Petersburg.

Zavoiko, F. 1914. Verovania, obriady i obychai velikorossov Vladimirskoi gubernii. Etnograficheskoe Obozrenie, kn. CIII-CIV, No. 3-4, pp. 81-178.

Zelenin, D. 1914; 1915. Opissanie rukopissei Uchenago Arkhiva Imperatorskago Russkago Geograficheskago Obshchestva. Vyp. I (1914); II (1915). Petrograd.

Zelenin, D. 1927. Russische (ostslavische) Volkskunde. Berlin \& Leipzig.

Zelenin, D. 1934. Istolkovanie perezhitochnykh religioznykh obriadov. Sovetskaia Etnografia, No. 5, pp. 3-16.

Zelenin, D. 1938. Dorevoliutsionnyi byt Mordvy. Sovetskaia Etnografia, No. 1, pp. 80-97. 